\title{
Erratum to: Conditional states and independence in D-posets
}

Ferdinand Chovanec • Eva Drobná •

František Kôpka $\cdot$ Oľga Nánásiová

Published online: 17 October 2009

(c) Springer-Verlag 2009

\section{Erratum to: Soft Comput}

DOI 10.1007/s00500-009-0487-0

Unfortunately, the author names have been wrongly published. The correct author names are given below: Ferdinand Chovanec, Eva Drobná, František Kôpka, Oľga Nánásiová.

F. Kôpka is deceased.

The online version of the original article can be found under doi:10.1007/s00500-009-0487-0.

F. Chovanec $(\bowtie) \cdot$ E. Drobná

Department of Natural Sciences, Academy of Armed Forces, P.O. Box 45, 03101 Liptovský Mikuláš, Slovak Republic

e-mail: ferdinand.chovanec@aos.sk

E. Drobná

e-mail: eva.drobna@aos.sk

O. Nánásiová

Department of Mathematics and Descriptive Geometry,

Faculty of Civil Engineering, Slovak Technical University,

Radlinského 11, 81368 Bratislava, Slovak Republic

e-mail: olga@vox.svf.stuba.sk

F. Chovanec $\cdot$ E. Drobná

Mathematical Institute, Slovak Academy of Sciences,

Štefánikova 49, 81473 Bratislava, Slovak Republic 